Rev. Inst. Flor. v. 29 n. 1 p. $129-133$ jun. 2017

http://dx.doi.org/10.24278/2178-5031.201729108

ISSN impresso 0103-2674/on-line 2178-5031

\title{
BIRDS CONSUMING FRUITS OF Varronia curassavica Jacq. (BORAGINACEAE) IN SOUTHEASTERN BRAZIL (SCIENTIFIC NOTE) ${ }^{1}$
}

\section{AVES CONSUMIDORAS DOS FRUTOS DE Varronia curassavica Jacq. (BORAGINACEAE) NO SUDESTE DO BRASIL (NOTA CIENTÍFICA)}

\author{
Alexsander Zamorano ANTUNES ${ }^{2,3}$; João Batista BAITELLO²; \\ Mariana Lopes CAMPAGNOLI²
}

\begin{abstract}
The Tropical Black Sage Varronia curassavica Jacq. is a widespread shrub in Brazil, which has become invasive in some parts of the world. We recorded 24 bird species consuming its fruits and potentially dispersing its seeds at Alberto Löfgren State Park, state of São Paulo, southeastern Brazil. It was first cultivated at this location, and despite the fact that it already is spreading naturally, the shrub remains restricted to more altered sites and does not constitute a threat to local biota.
\end{abstract}

Keywords: Atlantic Forest; frugivory; invasive species; Thraupidae.

RESUMO - A erva-baleeira Varronia curassavica Jacq. é um arbusto amplamente disseminado no Brasil e que se tornou invasor em alguns locais do mundo. Nós registramos 24 espécies de aves consumindo seus frutos e potencialmente disseminando suas sementes no Parque Estadual Alberto Löfgren, São Paulo. Nesse local, ela foi inicialmente cultivada e, apesar de já estar se disseminando naturalmente, permanece restrita a áreas mais alteradas, não constituindo no momento ameaça à biota local.

Palavras-chave: Mata Atlântica; frugivoria; espécies exóticas invasoras; Thraupidae.

\section{INTRODUCTION}

The Tropical Black Sage Varronia curassavica Jacq., Boraginaceae, is a shrubby nanophanerophyte (up to $2 \mathrm{~m}$ ), widely distributed in Brazil's beaches, sandbanks, dunes, forests and savannas from Piaú to Rio Grande do Sul. Its synonyms are: Cordia curassavica Jacq. Roem. \& Schult. and Cordia verbenaceae DC. (Stapf, 2015). Brazilian popular names are: erva-baleeira, balieira, baleira, maria-preta, pimenteira, erva-baleira and maria-milagrosa.
Growth is more significant in width than height, forming short but large canopies. It occurs in areas in the first stages of ecological succession, flowering and fruiting throughout the year (Ranga, 2012). Inflorescences contains 20 to 35 white flowers; the fruits are globular and flat to slightly obconical, showing a small umbo at the top (Ranga, 2012). The pulp is sweet and not very thick because of the large single seed inside (Barroso et al., 1999). Different from the flower, the fruit is very attractive to frugivorous animals due to its intense reddish color. 
Despite the few records of Brazilian bird species consuming Varronia curassavica, Large Elaenia Elaenia spectabilis Pelzeln, 1868 (Marini and Cavalcanti, 1998) and Turquoise Tanager Tangara mexicana (Linnaeus, 1766) (Snow and Snow, 1971) dispersion is ornithocoric (Dassanayake and Fosberg, 1991; United States Department of Agriculture - USDA, 2013).

The Tropical Black Sage has become an invasive exotic species in croplands and urban areas in some countries outside the Americas (USDA, 2013) and bird dispersion was one of the many factors that enabled Mauritius Island to be colonized by this species (USDA, 2013).

This paper described the bird assemblage consuming Tropical Black Sage fruits in Alberto Löfgren State Park, São Paulo, southeastern Brazil.

\section{MATERIAL AND METHODS}

We carried our observations at the Instituto Florestal administrative area, in Alberto Löfgren State Park - PEAL (2327'43"S, 46 37'59'W; altitude $723 \mathrm{~m}$ ). The study area included a small swamp at the edge of a secondary forest patch, where the Tropical Black Sage individuals were present.
Data collection took place in October and November 2015 and 2016, and April and May 2017. Total bird sampling effort resulted in 60 hours of nonstandard observations at different times of day, where all the species observed consuming Black Sage fruits were recorded. We used $8 \times 40$ binoculars, along with Canon SX60 and Nikon Coolpix P900 cameras.

We followed the nomenclature adopted by Stapf (2015) for the genus Varronia and Piacentini et al. (2015) for birds.

\section{RESULTS AND DISCUSSION}

We recorded 24 bird species consuming Varronia fruits (Table 1). In 2015 we observed Brazilian Tanager Ramphocelus bresilius (Linnaeus, 1766) and Green-headed Tanager Tangara seledon (Statius Muller, 1776) stocking fruits in the beak before swallowing or leaving the observation area (Figures 1 e 2), probably to feed young elsewhere. A pair of Brazilian Tanager have been seen accompanied by two juveniles in October 2014 and November 2015. The fructification of Tropical Black Sage in 2015 coincided with departure of the juvenile, which was recorded feeding on its own and with the help of its father.

Table 1. Bird species recorded feeding on Tropical Black Sage Varronia curassavica Jacq. fruits at Alberto Löfgren State Park.

Tabela 1. Aves registradas consumindo os frutos da erva-baleeira Varronia curassavica Jacq. no Parque Estadual Alberto Löfgren.

\begin{tabular}{ll}
\hline Taxons & English name \\
\hline $\begin{aligned} \text { Galliformes Linnaeus, 1758 } \\
\text { Cracidae Rafinesque, } 1815\end{aligned}$ \\
$\quad$ Penelope obscura Temminck, 1815 & \\
Passeriformes Linnaeus, 1758 & Dusky-legged Guan \\
Tyrannidae Vigors, 1825 & \\
Camptostoma obsoletum (Temminck, 1824) & Southern Beardless-Tyrannulet \\
Elaenia mesoleuca (Deppe, 1830) & Olivaceous Elaenia \\
Phyllomyias fasciatus (Thunberg, 1822) & Planalto Tyrannulet \\
Pitangus sulphuratus (Linnaeus, 1766) & Great Kiskadee \\
Myiodynastes maculatus (Statius Muller, 1776) & Streaked Flycatcher \\
Myiozetetes similis (Spix, 1825) & Social Flycatcher
\end{tabular}

continua to be continued 
ANTUNES, A.Z.; BAITELLO, J.B.; CAMPAGNOLI, M.L. Birds consuming fruits of Varronia curassavica.

continuação - Tabela 1

continuation - Table 1

\begin{tabular}{lll}
\hline Taxons & English name \\
\hline & Vireonidae Swainson, 1837 & \\
Cyclarhis gujanensis (Gmelin, 1789) & Rufous-browed Peppershrike \\
Vireo chivi (Vieillot, 1817) & Chivi Vireo \\
Turdidae Rafinesque, 1815 & \\
Turdus leucomelas Vieillot, 1818 & Pale-breasted Thrush \\
Turdus rufiventris Vieillot, 1818 & Rufous-bellied Thrush \\
Thraupidae Cabanis, 1847 & \\
Coereba flaveola (Linnaeus, 1758) & Bananaquit \\
Thlypopsis sordida (d'Orbigny \& Lafresnaye, 1837) & Orange-headed Tanager \\
Tachyphonus coronatus (Vieillot, 1822) & Ruby-crowned Tanager \\
Ramphocelus bresilius (Linnaeus, 1766) & Brazilian Tanager \\
Tangara seledon (Statius Muller, 1776) & Green-headed Tanager \\
Tangara cyanoventris (Vieillot, 1819) & Gilt-edged Tanager \\
Tangara desmaresti (Vieillot, 1819) & Brassy-breasted Tanager \\
Tangara sayaca (Linnaeus, 1766) & Sayaca Tanager \\
Tangara palmarum (Wied, 1823) & Palm Tanager \\
Dacnis cayana (Linnaeus, 1766) & Blue Dacnis \\
Saltator similis d'Orbigny \& Lafresnaye, 1837 & Green-winged Saltator \\
Fringillidae Leach, 1820 & \\
Euphonia violacea (Linnaeus, 1758) & Violaceous Euphonia \\
Euphonia pectoralis (Latham, 1801) & Chestnut-bellied Euphonia \\
\hline
\end{tabular}

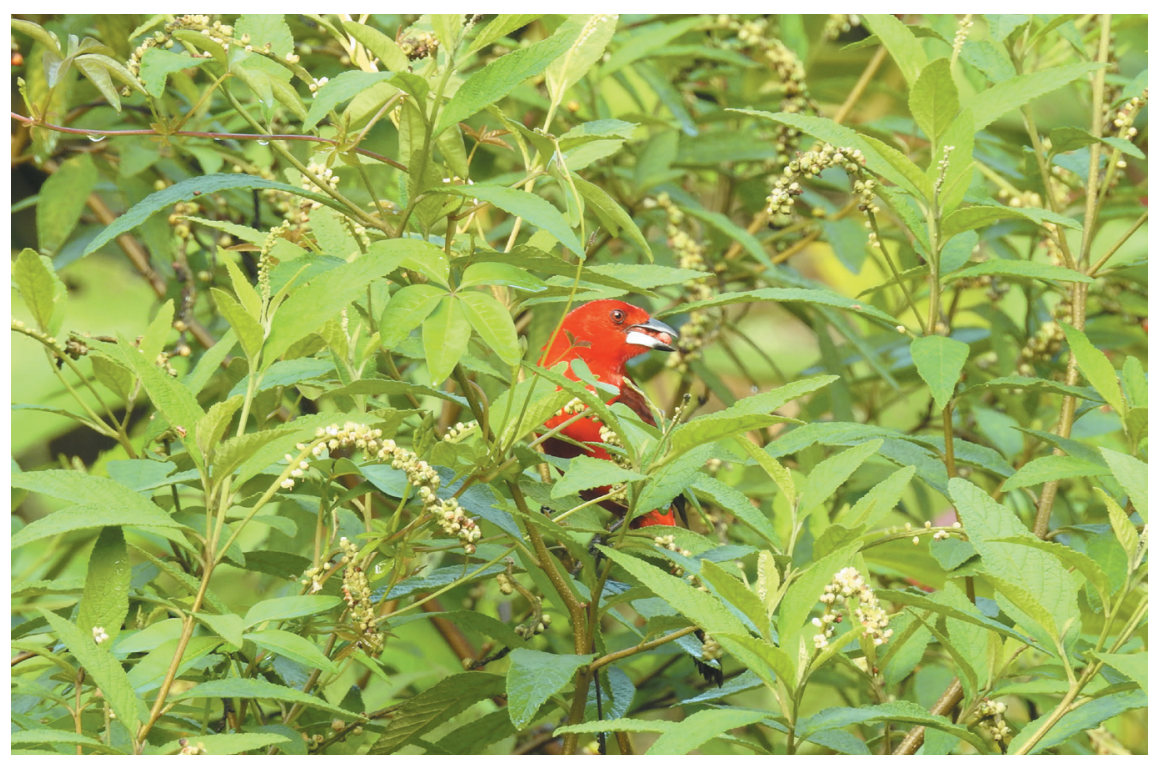

Figure 1. A male Brazilian Tanager Ramphocelus bresilius (Linnaeus, 1766) eating Tropical Black Sage fruit at Alberto Löfgren State Park. (C) J.B. Baitello.

Figura 1. Um tiê-sangue Ramphocelus bresilius (Linnaeus, 1766) macho consumindo frutos de erva-baleeira no Parque Estadual Alberto Löfgren. (C) J.B. Baitello. 


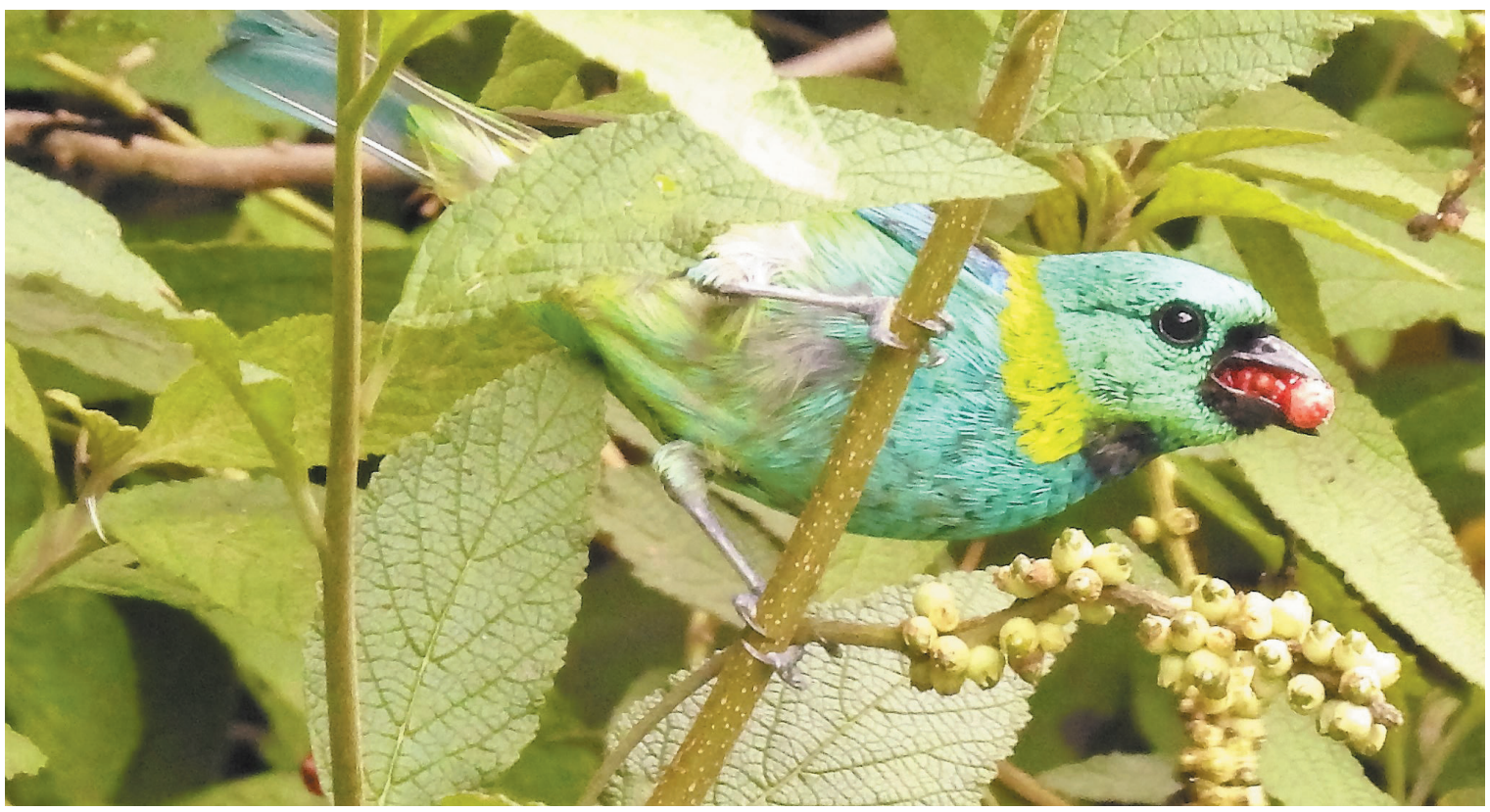

Figure 2. A female Green-headed Tanager Tangara seledon (Statius Muller, 1776) with two Tropical Black Sage fruits in the beak at Alberto Löfgren State Park. (C) J.B. Baitello.

Figura 2. Uma saíra-sete-cores Tangara seledon (Statius Muller, 1776) fêmea com dois frutos de erva-baleeira no bico, no Parque Estadual Alberto Löfgren. (C) J.B. Baitello.

Vieira and Silva (1997) recorded 19 bird species consuming fruits of Varronia multispicata (Cham.) Borhidi. in eastern Amazonia, a result similar to ours. Those authors found low individual fruit set, but concluded that the aggregate distribution and synchronized fruit production by the individuals assured a great quantity of fruits to be available simultaneously for the birds in a given patch.

In the late 1990s, three Tropical Black Sage individuals from Ilha Anchieta, Ubatuba - SP, were planted at PEAL (Rejane Esteves, personal communication). Another four individuals established themselves next to the study area, $11.42 \mathrm{~m}$ and $24 \mathrm{~m}$ away from the initial shrubs, probably due to bird dispersion. All studied individuals were at the forest edge, indicating how important light conditions are to its establishment (Green et al., 2004).

Despite invasion potential and local bird attractiveness, it seems that the establishment of Tropical Black Sage is probably limited by light conditions. Thus, it should not be a priority in the management of alien species carried out in the Alberto Löfgren State Park.

\section{ACKNOWLEDGMENTS}

We would like to thank Instituto Florestal/ COTEC (Process SMA 260108-008.500/2009), as well as the park manager of Alberto Löfgren State Park, Roselaine Barros Machado, for granting access and permission to study. CEMAVE and ICMBio (SISBIO 29073-4 and CEMAVE 1256/7) provided permits for bird captures and banding. We thank Rejane Esteves for providing information on introduction of Tropical Black Sage in PEAL. Thanks to anonymous reviewers for helpful comments and suggestions.

\section{REFERENCES}

BARROSO, G.M. et al. Frutos e sementes: morfologia aplicada à sistemática de dicotiledôneas. Viçosa-MG: Universidade Federal de Viçosa, 1999. 443 p.

DASSANAYAKE, M.D.; FOSBERG, F.R. (Ed.). $A$ revised handbook to the flora of Ceylon. New Delhi: Model Press, 1991. v. VII, 439 p. 
GREEN, P.T.; LAKE, P.S.; O’DOWD, D.J. Resistance of island rainforest to invasion by alien plants: influence of microhabitat and herbivory on seedling performance. Biological Invasions, v. 6, n. 1, p. 1-9, 2004.

MARINI, M.A.; CAVALCANTI, R.B. Frugivory by Elaenia flycatchers. Hornero, v. 15, n. 1, p. 47-50, 1998.

PIACENTINI, V.Q. et al. Annotated checklist of the birds of Brazil by the Brazilian Ornithological Records Committee/Lista comentada das aves do Brasil pelo Comitê Brasileiro de Registros Ornitológicos. Revista Brasileira de Ornitologia, v. 23, n. 2, p. 91-298, 2015.

RANGA, N.T. Cordia L. In: WANDERLEY, M.G.L. et al. (Ed.). Flora Fanerogâmica do estado de São Paulo. São Paulo: Instituto de Botânica, 2012. v. 7, p. 118-126.

SNOW, B.K.; SNOW, D.W. The feeding ecology of tanagers and honeycreepers in Trinidad. Auk, v. 88, n. 2, p. 291-322, 1971.

STAPF, M.N.S. Varronia. In: JARDIM BOTÂNICO DO RIO DE JANEIRO (Ed.). Lista de espécies da flora do Brasil. Available from: $<$ http://floradobrasil.jbrj.gov.br/jabot/floradobrasil/ FB105435/>. Access on: 4 Dec. 2015.

UNITED STATES DEPARTMENT OF AGRICULTURE - USDA. Weed risk assessment for Cordia curassavica (Jacq.) Roem. \& Schult. (Boraginaceae) - black sage. 2013. Available from: $<$ https://www.aphis.usda.gov/plant_health/ plant_pest_info/weeds/downloads/wra/ Cordia_curassavica_WRA.pdf $>$. Access on: 4 Dec. 2015.

VIEIRA, I.C.G.; SILVA, J.M.C. Phenology, fruit set and dispersal of Cordia multispicata Cham., an important weed shrub of abandoned pastures in eastern Amazonia. Revista Brasileira de Botânica, v. 20, n. 1, p. 51-56, 1997. 